\title{
HPLC analysis of non-enzymatic antioxidants in Azolla caroliniana (Pteridopsida) subjected to UV-B
}

\author{
E,M. Mostafa and M. M. Ibrahim \\ Botany and Microbiology Department, Faculty of Science, Alexandria University, \\ 21511, Alexandria, Egypt.
}

\section{ABSTRACT}

The ultrastructure of chloroplast and quantified antioxidant compounds such as $\alpha$-tocopherol, ascorbic acid and beta carotene, semi quantitatively by comparing the peak areas of HPLC chromatograms, were affected considerably in response to exposure of Azolla caroliniana to UV-B radiation for 24 and $48 \mathrm{~h}$. The results show that the most striking effect of the enhanced UV-B treatment on the ultrastructure of A. caroliniana was observed after $48 \mathrm{~h}$ as markedly widened chloroplast area occupied by large amount of plastoglobuli in stressed fronds. Prolonged UV-B exposure of $A$. caroliniana for $48 \mathrm{~h}$ resulted in a reduction in peaks area for for $\alpha$ tocopherol, ascorbic acid and beta-carotene. The results show that changes in the chromatogram of non-enzymatic antioxidants were correlated with the duration of exposure to UV-B radiation. These antioxidant metabolites play a vital role in protecting A. caroliniana to a certain limit against UV-B radiation.

Keywords: HPLC- antioxidants- Azolla caroliniana- UV-B

\section{INTRODUCTION}

Human impact through urban activates and industrial gas emissions such as chlorofluorocarbons and nitrogen oxides in the stratosphere was found to explain the low level of ozone concentration in the last 30 years (Solomon, 2008). Therefore, it still remains interesting to investigate the effects of elevated UV-B radiation on various aspects of plant growth, continuously (Solomon, 2008; Kakani et al., 2003 and Wang et al., 2006).

Plants have evolved mechanisms to avoid and repair UV radiation oxidative stress damage, and the free radicals caused by UV tend to be involved in the induction of antioxidant defense system. In previous studies, it has been concluded that plant growth and biomass accumulation could result from complex interactions between harmful direct and indirect effects of UV and a series of counteracting repair mechanisms (Lesser et al., 1994 and Ibrahim and Mostafa, 2007). It has been shown that the composition of the aquatic fern Azolla varies profoundly according to environmental conditions and the species (Lumpkin and Plucknett, 2008; Van Hove, 1987 and Sanginga, N. and Van Hove, 1989).

Reactive oxygen species (ROS) such as superoxide radicals $\left(\mathrm{O}_{2}^{-}\right)$, singlet oxygen $\left({ }^{1} \mathrm{O}_{2}\right)$, hydrogen peroxide $\left(\mathrm{H}_{2} \mathrm{O}_{2}\right)$ and hydroxyl radical $(\mathrm{OH})$ are present in all plants in varying degrees as a result of normal aerobic metabolism. Under biotic or abiotic stress, production and removal of ROS are controlled by an array of enzymatic and non-enzymatic antioxidant mechanisms in plants reducing damage to DNA, protein, and lipids (Foyer et al., 1994; Singh et al., 2006 and Ibrahim and Bafeel, 2011). Non-enzymatic antioxidant defense systems consist of low molecular mass compounds such as ascorbic acid and glutathione which are active in the aqueous 
phase, whereas the lipophilic antioxidants (such as A-tocopherol and $\beta$-carotene) are active in the membrane environment (Asada, 1994).

Alpha-tocopherol is known for its protective effect against lipid peroxidation of biological membranes via peroxyl and alkoxyl radical scavenging (Burton et al., 1982). Beta carotene content of Azolla is of particular interest since this nutrient is usually required as a supplement in animal feeding as physiological antioxidant and as a precursor of vitamin A, a multipurpose vitamin essential for animal health. Also, other function of $\beta$-carotene is photoreceptive, because it acts as a pigment antenna in the photosynthesis process. Relatively low concentrations of $\beta$-carotene are able to protect plants against oxidative damage which initiated by singlet oxygen (Lowe et al., 1999).

Microscopic studies could serve as an additional and sensitive tool in the assessment of plant responses to UV-B. By means of electron microscopy, early stress responses can be observed in the cell structure before the first macroscopic visible symptoms occur (Holopainen et al., 1992). Special emphasis was put on chloroplast ultrastructure because alterations in the chloroplast could lead to changes in carbon assimilation and biomass accumulation (Ibrahim and Mostafa, 2007). Furthermore, it is well established that chloroplast structure is altered by UV-B usually before other cell organelles (Holopainen et al., 1996).

Azolla, is an aquatic fern native of Asia and Africa. There is a symbiotic relationship between Azolla and a nitrogen fixer, the cyanobacteria Anabaena azollae which invades certain cavities on the dorsal lobes of the leaves on the ventral surface. It is used as a biofertilizer to crops because of its ability to fix dinitrogen at high rates and low cost.

Our previous study has shown that, the vegetative growth, the photosynthetic pigments in addition to the UV-absorbing compounds such as phenolics, flavonoids and anthocyanins in Azolla caroliniana were strongly affected by the duration of exposure to UV-B radiation (Ibrahim and Mostafa, 2007). In this study, changes in reservation non-enzymatic antioxidant metabolites and ultrastructure of chloroplast were investigated in relation to UV damage in the aquatic fern Azolla caroliniana.

\section{MATERIALS AND METHODS}

\section{Plants and cultivation}

Azolla caroliniana Wild (Known as water velvet) was provided by Prof. Weam El-Aggan in year 1982 from Catholic University of louvain, Belgium, it was identified by Prof. Peters G.A., Kettering laboratory Yellow Springs, Ohio 45387. The plants were acclimated in the green-house of the Faculty of Science, Alexandria, in $2500 \mathrm{~cm}^{3}$ polyethylene vessels which were filled with a nitrogen free, modified $\left[\mathrm{KNO}_{3}\right.$ and $\mathrm{Ca}\left(\mathrm{NO}_{3}\right)_{2}$ were replaced by $\mathrm{KCl}$ and $\mathrm{CaCl}_{2}$, respectively] Hoagland solution (2/5 concentration, $\mathrm{pH} 5.1$ ). About $5 \mathrm{~g}$ (fresh mass) of Azolla from the stock material were inoculated in each vessel to make a new subculture, and so on. The plants were freed from epiphytic microorganisms by thorough washing with distilled water. The cultures were grown in a growth chamber under 16-h photoperiod at irradiance of $1200 \mu \mathrm{mol} \mathrm{m} \mathrm{m}^{-2} \mathrm{~S}^{-1}$ (cool white fluorescent tubes) and (light/dark) temperature of $28-30 / 20-25{ }^{\circ} \mathrm{C}$ (Stock culture). Before being used the plants were surface sterilized with $0.2 \%$ Clorox (El-Aggan, 1982), then thoroughly washed with water. 


\section{Treatments}

Five grams of Azolla plants were transferred to $250 \mathrm{~cm}^{3}$ vessels containing $2 / 5$ modified Hoagland solution at laboratory conditions for $7 \mathrm{~d}$ then exposed to UV-B radiation supplied by three UV-emitting tubes (TL12/100W/01, Philips, Holland) positioned $50 \mathrm{~cm}$ above leaf level .Rack height, lamp spacing and lamp power were adjusted as described by Ibrahim and Mostafa (2007) to maintain a total daily flux of biologically effective UV-B radiation doses $5.75 \mathrm{KJ} \mathrm{m}^{-2} \mathrm{~d}^{-1}$. Plants were rotated under the lamp banks in an attempt to minimize potential effects resulting from microenvironment variation for 0,24 and $48 \mathrm{~h}$. Samples were taken for chemical analyses and ultrastructure examination.

\section{Methods}

Transverse sections of Azolla plants were examined by both light microscope (LM) and transmission electron microscopy (TEM). Small pieces $\left(1 \mathrm{~mm}^{2}\right)$ of Azolla caroliniana with irregular brown patches caused by UV-B and of dark-green fronds (control) were taken for electron microscopy analysis. Fragments of the control and treated fronds were fixed in $3 \%$ glutaraldehyde in $0.1 \mathrm{M}$ cacodylate buffer, $\mathrm{pH} 6.8$, for $2 \mathrm{~h}$ at $0-4{ }^{\circ} \mathrm{C}$. After washing with the same buffer, small pieces of leaves were post fixed in $1 \% \mathrm{OsO}_{4}$ at $0-4^{\circ} \mathrm{C}$ for $2 \mathrm{~h}$. The material was dehydrated in ethanol, than propylene oxide and afterwards embedded in Spurr-Epon mixture. Ultrathin sections cut on a Reichert Ultratome were stained with uranyl acetate and lead citrate according to Reinolds (1963) procedure and then examined by Jeol $100 \mathrm{CX}$ electron microscope, Japan. Three digital TEM micrographs were taken from random cells, these magnification were chosen to discern clearly the structure of the chloroplasts.

\section{HPLC analysis of $\alpha$ - tocopherol, ascorbic acid and $\beta$-carotene Extraction}

Alpha-tocopherol was extracted according to the method of Ubaldi et al. (2005). Azolla fronds were extracted with $30 \mathrm{ml}$ ether (twice). Ether phases were combined and transferred in the separating funnel, rinsed 6 times with $50 \mathrm{ml}$ water and recovered in a round-bottom flask. Separating funnel was rinsed with $10 \mathrm{ml}$ ether recovered in a round-bottom flask. Then, the test material was evaporated to dryness in a rotary evaporator under partial vacuum at water-bath at $45{ }^{\circ} \mathrm{C}$ for $5 \mathrm{~min}$. After cooling, test material was recovered with $5 \mathrm{ml}$ methanol, well mixed and transferred in a glass tube, centrifuged at $4000 \mathrm{rpm}$ for $5 \mathrm{~min}$.

Ascorbic acid (vitamin C) was extracted according to the modified method of Abdulnabi et al. (1997). Ten gram of Azolla fronds were homogenized with an extracting solution containing meta-phosphoric acid $(0.3 \mathrm{M})$ and acetic acid $(1.4 \mathrm{M})$. The mixture was placed in a conical flask (wrapped with aluminum foil) and agitated at $100 \mathrm{rpm}$ with the aid of an orbital shaker for $15 \mathrm{~min}$ at room temperature. The mixture was then filtered through a Whatman No. 4 filter paper to obtain a clear extract.

The $\beta$-carotene in the sample was extracted according to the method described by Tee et al. (1996) with slight modification (Ismail and Fun, 2003). The sample (10 g) was added with $40 \mathrm{ml}$ of $99.8 \%$ ethanol and $10 \mathrm{ml}$ of $100 \%(\mathrm{w} / \mathrm{v})$ potassium hydroxide, and homogenized for 3 min using a blender. The mixture was saponified by means of a refluxing apparatus, and heated using a heating mantle for $30 \mathrm{~min}$, and then cooled to room temperature. The mixture was frequently agitated to avoid any aggregation. For the extraction step, the mixture was transferred into a separation funnel and $50 \mathrm{ml}$ of $\mathrm{n}$-hexane was added. The funnel was inverted, vented and then shaken vigorously for a few seconds, and the layers were allowed to separate. The upper layer (hexane extract) was pipettered out, and the aqueous layer was re- 
extracted twice, each time with $50 \mathrm{ml}$ of n-hexane. The extract was then filtered through anhydrous sodium sulphate to remove any water residue.

\section{Analysis}

Alpha-tocopherol, vitamin $C$ and $B$-carotene were determined by a reverse-phase HPLC technique. Hewlett Packard HPLC Series 1100 (USA) equipped with degasser, quaternary pump, auto-sampler and diode array detector was used. A Ultrasphere octadecylsilyl (ODS) Hypersil $\mathrm{C}_{18}, 5 \mathrm{~mm}$ particle size, in a $250 \mathrm{~mm}$ length $\mathrm{x} 4.0 \mathrm{~mm}$ I.D stainless steel column (Hewlett Packard) was used. The separation and identification conditions for the antioxidants are tabulated in Table 1.

Table 1: HPLC conditions for separation and identification of vitamin E, vitamin C and beta-carotene.

\begin{tabular}{|c|c|c|c|}
\hline \multirow{2}{*}{ Parameters } & \multicolumn{3}{|c|}{ Conditions } \\
\cline { 2 - 4 } Mobile phases & Vitamin E & Vitamin C & B-carotene \\
\hline \multirow{2}{*}{ Flow rate } & -Methanol & $\begin{array}{c}-0.1 \mathrm{M} \text { potassium acetate, } \\
\mathrm{pH} \mathrm{4.9} \\
\text {-Acetonitrile-water (50:50) }\end{array}$ & $\begin{array}{c}\text { - Acetonitrile- Methanol- } \\
\text { ethyl acetate (88-10-2) }\end{array}$ \\
\hline Detection & $1 \mathrm{ml} / \mathrm{min}$ & $1.5 \mathrm{ml} / \mathrm{min}$ & $1 \mathrm{ml} / \mathrm{min}$ \\
\hline
\end{tabular}

\section{RESULTS AND DISCUSSION}

The maximal daily UV-B doses varied between 1 and $2 \mathrm{KJ} \mathrm{m}^{-2} \mathrm{~d}^{-1}$, calculated by Behrenfeld et al. (1993) from incident irradiance at the Pacific Ocean's water surface in summer at med-latitudes. In our experiment the UV-B dose was reached to nearly 2.5 folds increase more than the maximal daily doses.

The most striking effect of the enhanced UV-B dose treatment on the ultrastructure of $A$. caroliniana was observed after $48 \mathrm{~h}$ exposure period as markedly widened chloroplast area occupied by large amount of plastoglobuli in stressed fronds (Fig. 1). On the other hand, plastoglobules were rarely or occasionally detected in the chloroplasts of the control fronds. The chloroplast membrane got significantly altered across treatment, especially those exposed to UV-B for $48 \mathrm{~h}$ relative to the control.

Deformation of chloroplasts structures may be due to oxidative damage under UV-B radiation. Stoyanova and Velikova (1997) and Tarhanen (1998) suggested that ROS disturb the ultrastructure of cell organelles, mostly plastids and mitochondria. In addition, the changes in chloroplast size followed by marked changes in the area of starch; also one notable difference in this study is that starch was readily detected in controlled grown Azolla caroliniana, while they were rarely observed in the UV-B treated Azolla (Fig.1). Lack of starch in the chloroplasts in response to UV-B exposure suggests little photosynthetic activity of the fronds towards the UV-B exposure. Plastoglobuli (lipoprotein sub-compartments structure) consist mainly of triacylglycerols, plastohydroquinone and $\alpha$-tocopherol and it has been reported that their numbers increase during the up-regulation of plastid lipid metabolism in response to different stresses and during senescence (Murphy, 2001). In our experiment plastoglobules size, number and intensities of $A$. caroliniana subjected to UV-B radiation were linearly increased with the UV-B dose till the end of the experiment. These finding are in agreement with observations of the increase in the number and/or size of plastoglobules in response to abiotic stresses in grapevine (Britvec et al., 2001). Also, the cell wall increased in thickness under elevated UV-B exposure for $24 \mathrm{~h}$, then completely deformed after $48 \mathrm{~h}$ (Ibrahim and Mostafa, 2001). Thinner cell walls under UV-B exposure may result from a delay in cell wall differentiation (Fig.1). Cell wall measurements are also prone to inaccuracies because 
the cell wall thickness varies considerably between and within cells. Similar observations in needles of Norway spruce were discussed by Kivimaenpaa et al. (2003). Ibrahim and Mostafa (2007) explained that after application of UV-B radiation for $48 \mathrm{~h}$ on Azolla plant, the content of deformed chloroplasts increased up to $95 \%$ and the cell cross-sectional area occupied by chloroplasts was significantly increased in a linear manner with increasing the duration of exposure to UV-B.

Chromatographic characterization of $\alpha$-tocopherol showed great quantative variations, whereas, ascorbic acid and $\beta$-carotene showed marked changes in both number and area of the characterized peaks. In our study, the chromatogram of $\alpha$ tocopherol showed three different peaks throughout the UV-B exposure periods (Fig. 2). The peaks area were reduced after exposure of Azolla fronds to UV-B radiation for $48 \mathrm{~h}$ reached to $60 \%$ and $41 \%$ for peak 1 and 3, respectively in comparison to its exposure for $24 \mathrm{~h}$ (Table 2). On the other hand, there were an increase in peaks 1 and 3 area reached to $33 \%$ and $13 \%$ after exposure of Azolla fronds to UV-B radiation for $24 \mathrm{~h}$ in comparison to control, respectively.

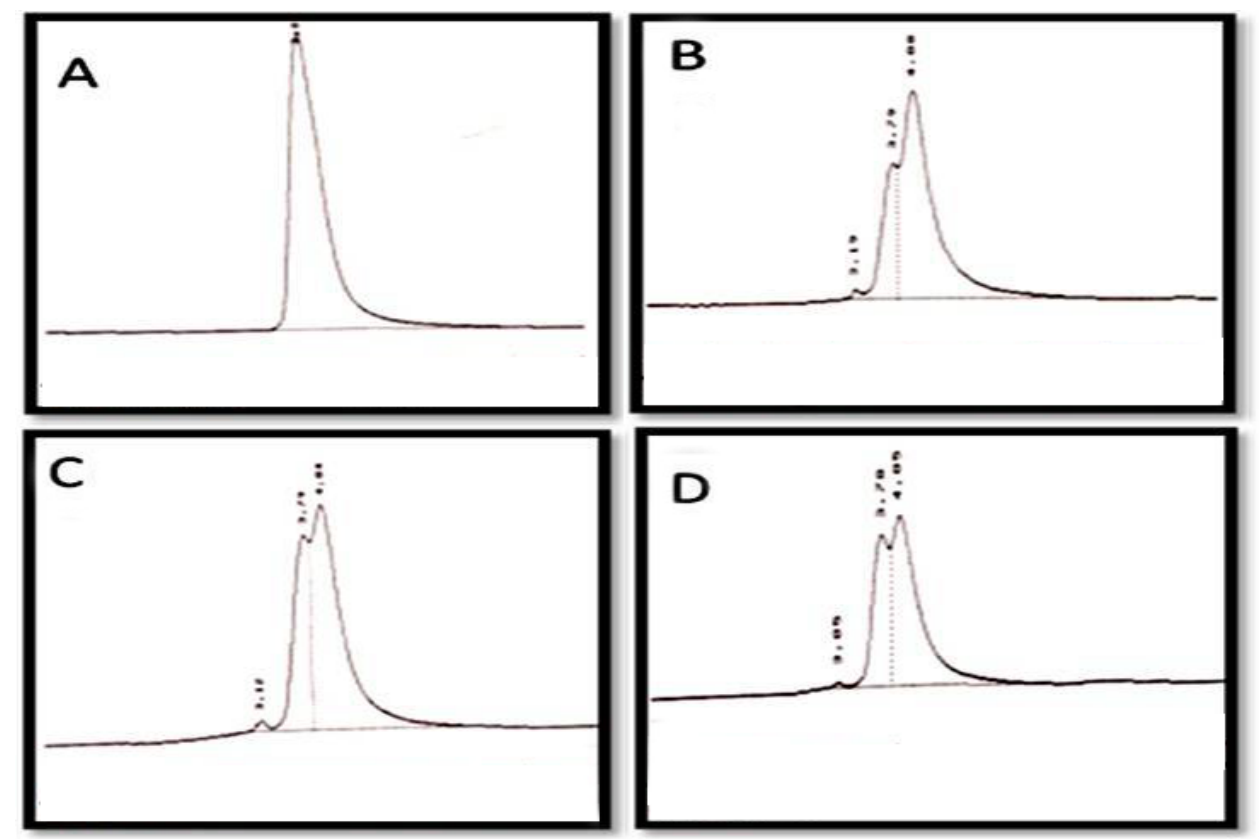

Fig. 2: Chromatogram of an extract of Azolla caroliniana obtained by HPLC. The $\alpha$-tocopherol was readily detected and quantified in this representative sample collected after the exposure of fronds to UV-B radiation for 24 and $48 \mathrm{~h}$. Assignment of peaks was conducted by comparing the retention time obtained for standards with the analysis of the characteristic peaks from the samples. A, standard; B, control; C and D, exposure to UV-B for 1 and $2 \mathrm{~d}$, respectively.

These results suggested the involvement of $\alpha$-tocopherols in the photoprotection of $A$. caroliniana against the oxidative stress caused by UV-B radiation.

Our results are consistent with the findings of other authors who found that the level of $\alpha$-tocopherol increases in plants that exposed to environmental stress which are susceptible to induce oxidative stress (Wildi and Lütz, 1996; Delong and Steffen, 1997; Fryer et al., 1998; Havaux et al., 2000 and Munné-Bosch and Alegre, 2000). Ascorbic acid is the most important metabolite, universal in photosynthetic eukaryotes (Smirnoff, 1996). After exposure of A. caroliniana fronds to UV-B radiation for $48 \mathrm{~h}$, peaks area for ascorbic acid were all markedly affected and reduced to a values reached 34,33 and $37.5 \%$, respectively in comparison to its exposure for $24 \mathrm{~h}$ (Table 2). 
Table 2: Chromatographic profile of $\alpha$-tocopherol, ascorbic acid and $\beta$-carotene in Azolla caroliniana subjected to UV-B radiation for 24 and 48 h. n.d., not detected.

\begin{tabular}{|c|c|c|c|c|c|c|c|}
\hline \multirow{3}{*}{ Compound } & \multirow{2}{*}{ Time } & \multicolumn{2}{|c|}{ Retention Time [min] } & \multicolumn{3}{|c|}{ Peak area $\left[\mathrm{Cm}^{2}\right]$} \\
\cline { 3 - 9 } & & Peak 1 & Peak 2 & Peak 3 & Peak 1 & Peak 2 & Peak 3 \\
\hline \multirow{4}{*}{$\alpha$-tocopherol } & Control & 3.23 & 3.78 & 4.03 & $15 \times 10^{-4}$ & 0.052 & 0.15 \\
\cline { 2 - 9 } & $24 \mathrm{~h}$ & 3.19 & 3.79 & 4.08 & $20 \times 10^{-4}$ & 0.054 & 0.17 \\
\cline { 2 - 9 } & $48 \mathrm{~h}$ & 3.05 & 3.78 & 4.05 & $8 \times 10^{-4}$ & 0.056 & 0.10 \\
\hline \multirow{3}{*}{ Ascorbic acid } & Control & 4.34 & 5.22 & n.d. & 0.050 & 0.015 & n.d. \\
\cline { 2 - 9 } & $24 \mathrm{~h}$ & 4.56 & 5.46 & 5.89 & 0.046 & 0.012 & 0.008 \\
\cline { 2 - 9 } & $48 \mathrm{~h}$ & 4.60 & 5.47 & 5.89 & 0.030 & 0.008 & 0.005 \\
\hline \multirow{3}{*}{$\beta$-Carotene } & Control & 3.18 & 3.76 & ------ & $7 \times 10^{-4}$ & 0.16 & ------ \\
\cline { 2 - 9 } & $24 \mathrm{~h}$ & 3.19 & 3.76 & ------ & $8 \times 10^{-4}$ & 0.15 & ------ \\
\cline { 2 - 8 } & $48 \mathrm{~h}$ & n.d. & 3.75 & ------ & n.d. & 0.13 & ------ \\
\hline
\end{tabular}

In control plants, two peaks only were detected (Fig. 3). Selvakumar (Selvakumar, 2008) recorded that UV-B treatment increased proportionally the ascorbic acid content of Vigna unguiculata and Crotalaria juncea plants depending on the dose used.

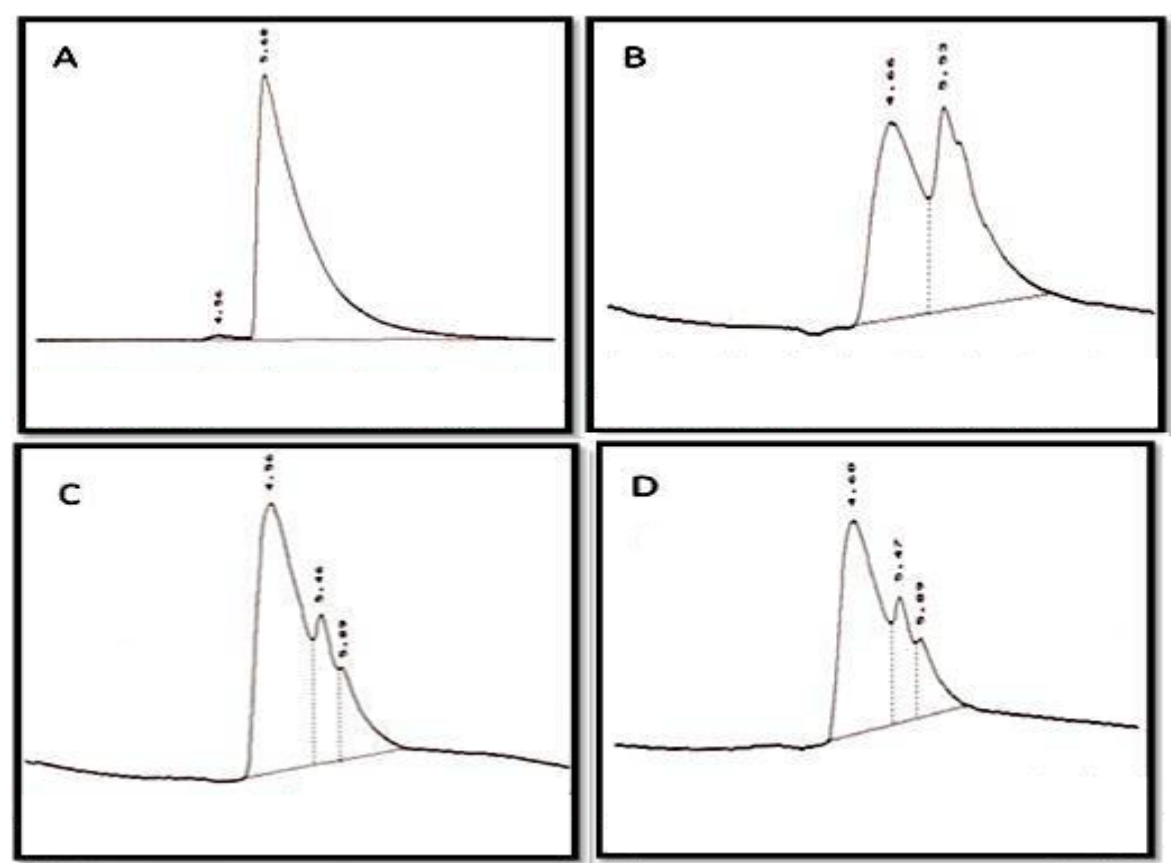

Fig. 3: Chromatogram of an extract of Azolla caroliniana obtained by HPLC. The ascorbic acid was readily detected and quantified in this representative sample collected after the exposure of fronds to UV-B radiation for 24 and $48 \mathrm{~h}$. Assignment of peaks was conducted by comparing the retention time obtained for standards with the analysis of the characteristic peaks from the samples. A, standard; B, control; C and D, exposure to UV-B for 1 and $2 \mathrm{~d}$, respectively.

Also, Kumari et al. (2010) observed an increase in ascorbic acid content of Acorus calamus, a medicinal plant, due to UV-B exposure at initial stage of sampling, 
whereas at later stages a decline was observed. Ascorbic acid acts as antioxidant, reacting directly with hydroxyl radical, single oxygen and superoxide radicals. Increase in ascorbic acid in plants after UV-B exposure compared with untreated plants were also manifested in several studies suggesting its induction due to UV-B stress (Hernandez et al., 1995; Costa et al., 2002 and Nasibi and Kalantari, 2005). The reduction in ascorbic acid could be explained due to increase activity of ascorbate peroxidase after UV-B exposure resulting into more consumption of ascorbic acid for effective quenching of oxyradicals (Kumari et al., 2010). Decline in ascorbic acid under UV-B stress was also reported by Agrawal and Rathore (2007) in wheat and mung bean.

After $24 \mathrm{~h}$ exposure of Azolla fronds to UV-B radiation, two peaks of $\beta$-carotene were characterized at retention time 3.19 and $3.76 \mathrm{~min}$ (Table 2). Whereas, the prolonged exposure to UV-B for $48 \mathrm{~h}$ resulted in a complete disappearance of the first peak and also a reduction in area of the second peak, compared with control plants and that exposed for $24 \mathrm{~h}$ to UV-B radiation (Fig. 4). Similarly, Hernando et al. (2005) suggested that exposure of Asteromonas sp. to UV-B and UV-A radiation for 3 $\mathrm{d}$ resulted in an increase in $\beta$-carotene content and a marked decrease was observed afterwards. B-carotene can directly quench singlet oxygen or prevent the formation of a chlorophyll triplet excited state (Young et al., 1997). The changes in A. caroliniana fronds after its exposure to UV-B radiation for $48 \mathrm{~h}$ could indicate severe effects which resulted in a decrease in $\beta$-carotene synthesis, suggesting its role as antioxidant in protection against injuries.

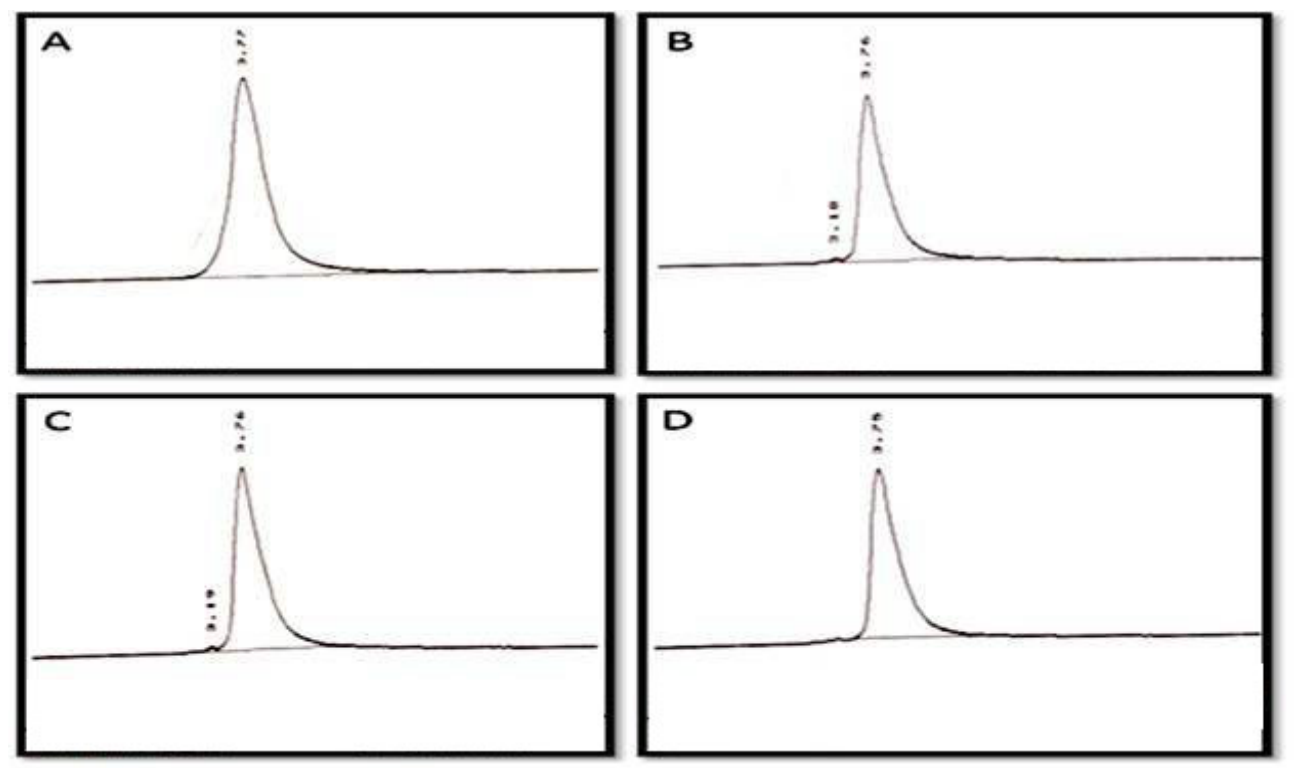

Fig. 4: Chromatogram of an extract of Azolla caroliniana obtained by HPLC. The $\beta$-carotene was readily detected and quantified in this representative sample collected after the exposure of the fronds to UV-B radiation for 24 and $48 \mathrm{~h}$. Assignment of peaks was conducted by comparing the retention time obtained for standards with the analysis of the characteristic peaks from the samples. A, standard; B, control; C and D, exposure to UV-B for 1 and $2 \mathrm{~d}$, respectively.

This study reports ultrastructural responses of Azolla caroliniana to prolonged exposure to UV-B radiation. The observed responses throughout the experiment indicated that prolonged exposure to UV-B radiation resulted in a marked deformation in the ultrastructure of chloroplast, which may be resulted in the destruction of photosynthetic activity. This damage indicated that activation of various antioxidants 
did not provide complete protection to Azolla caroliniana, especially which exposed to $\mathrm{UV}-\mathrm{B}$ radiation for $48 \mathrm{~h}$.

\section{REFERENCES}

Abdulnabi, A.A.; Emhemed, A.H.; Hussein, G.D. and Biacs, P. A. (1997). Determination of antioxidant vitamins in tomatoes. Food Chem. 60: 207-212.

Agrawal, S.B. and Rathore, D. (2007). Changes in oxidative stress defense system in wheat (Triticum aestivum L.) and mung bean (Vigna radiate L.) cultivars grown with and without nutrient and irradiated by supplemental ultraviolet-B. Environ. Exp. Bot. 59: 21-33.

Asada, K. (1994). The water-water cycle in the chloroplasts: Scavenging of active oxygen and dissipation of excess photons. Annu. Rev. Plant Physiol. Plant mol.

Biol. 50: 601-639.

Behrenfeld, M.; Hardy, J.; Gucinski, H.; Hanneman, A.; Lee, H. and Wones, A. (1993). Effects of ultraviolet-B radiation on primary production along latitudinal transects in the South Pacific Ocean. h4ar Environ Res. 35: 349-63.

Britvec, M.; Reichenauer, T.; Soja, G.; Ljubesic, N.; Eid, M. and Pecina, M. (2001). Ultrastructure changes in grapevine chloroplasts caused by increased tropospheric ozone concentrations. Biologia Bratislava. 56:417-424.

Burton, G.W.; Joyce, A. and Ingold, K.U. (1982). First proof that vitamin E is major lipid-soluble, chain-breaking antioxidant in human blood plasma. Lancet. 2:327.

Costa, H.; Gallego, S. M. and Tomaro, M. L. (2002). Effects of ultraviolet-B radiation on antioxidant defense system in sunflower cotyledons. Plant Sci. 162: 939-945.

Delong, J.M. and Steffen, K.L. (1997). Photosynthetic function, lipid peroxidation and $\alpha$-tocopherol content in spinach leaves during exposure to UV-B radiation. Can J Plant Sci. 77: 453-459.

El-Aggan, W.H. (1982). A comparative study of the growth and nitrogenase activity of five Azolla species as affected by various environmental factors. Ph.D. Thesis, Universite Catholique De Louvain.

Foyer, C.H.; Lelandais, M. and Kunert, K.J. (1994). Photooxidative stress in plants. Physiol. Plant. 92: 696-717.

Fryer, M.J.; Andrews, J.R.; Oxborough, K.; Blowers, D.A. and Baker, N.R. (1998). Relationship between $\mathrm{CO}_{2}$ assimilation, photosynthetic electron transport, and active $\mathrm{O}-2$ metabolism in leaves of maize in the field during periods of low temperature. Plant Physiol. 116: 571-580.

Havaux, M.; Bonfils, J.P.; Lütz, C. and Niyogi, K.K. (2000). Photodamage of the photosynthetic apparatus and its dependence on the leaf developmental stage in the npq1 Arabidopsis mutant deficient in the xanthophyll cycle enzyme violaxanthin de-epoxidase. Plant Physiol. 124: 273-284.

Hernandez, J. A.; Olmos, E.; Corpas, F. J.; Sevilla F. and del Rio L. A. (1995). Saltinduced oxidative stress in chloroplast pea plants. Plant Sci. 105: 151-167.

Hernando, M.P.; Malanga, G.F. and Ferreyra, G.A. (2005); Oxidative stress and antioxidant defenses generated by solar UV in a Subantarctic marine phytoflagellate. Sci. Mar. 69: 287-295.

Holopainen, T.; Anttonen, S.; Palomaki V.; Kainulainen, P. and Holopainen, J. K. (1996). Needle ultrastructure and starch content in Scots pine and Norway spruce after ozone fumigation. Can. J. Bot. 74: 67-76.

Holopainen, T.; Anttonen, S.; Wulff, A.; Palomaki V. and Karenlampi L. (1992). Comparative evaluation of the effects of gaseous pollutants, acidic deposition 
and mineral deficiencies: structural changes in the cells of forest plants. Agric. Eco. Eviron. 42: 365-398.

Ibrahim, M. M. and Mostafa, E. M. (2007). UV-B effect on constituents of Azolla caroliniana. Z. Naturforsch. 62 (c): 246-252.

Ibrahim, M. M. and Bafeel, S. O. (2011). Molecular and Physiological Aspects for Lepidium sativum Tolerance in Response to Lead Toxicity. Fresenius Environmental bulletin. 20 (8): 1871-1879.

Ismail, A. and Fun, C.S. (2003). Determination of vitamin C, ß-carotene and Riboflavin contents in five green vegetables organically and conventionally grown. Mal J Nutr. 9(1): 31-39.

Kakani, V.G.; Reddy, K.R.; Zhao, D. and Sailaja (2003); Field crop response to ultraviolet -B radiation: A review. Agric. For. Meteorol. 120: 191-218.

Kivimaenpaa, M.; Sutinen, S.; Karlsson, P.E. and Sellden G. (2003). Cell structural changes in the needles of Norway spruce exposed to long term ozone and drought. Annals of Botany. 92: 779-793.

Kumari, R.; Singh, S. and Agrawal, S. B. (2010). Response of ultraviolet-B induced antioxidant defense system in a medical plant, Acorus calamus. J. Environmental Biology. 31: 907-911.

Lesser, M. P.; Cullen, J. J. and Neale, P. J. (1994). Photoinhibition of photosynthesis in the marine diatom Thalassiossira pseudonono during acute exposure to ultraviolet-B radiation: relative importance of damage and repair. J. Phycol. 30: 183-192.

Lowe, G.M.; Booth, L.A.; Young, A. J. and Bilton, R. F. (1999). Lycopene and betacarotene protect against oxidative damage in HT29 cells at low concentrations but rapidly lose this capacity at higher doses. Free Radic Res. 30 (2): 141-151.

Lumpkin, T.A. and Plucknett, D.L. (1982). Azolla as a Green Manure: Use and Management in Crop Production. Westview Tropical Agriculture Series, Westview, Boulder, $230 \mathrm{pp}$.

Munné-Bosch, S. and Alegre, L. (2000). Changes in carotenoids, tocopherols and diterpenes during drought and recovery, and the biological significance of chlorophyll loss in Rosmarinus officinalis plants. Planta. 210: 925-931.

Murphy, D. J. (2001). The biogenesis and functions of lipid bodies in animals, plants and microorganisms.- Progress in Lipid Research. 40: 325-438.

Nasibi, F. and Kalantari, K.M. (2005). The effects of UV-A, UV-B and UV-C on protein and ascorbate content, lipid peroxidation and biosynthesis of screening compounds in Brassica napus. Iran. J. Sci. Technol. Transaction A-Science Winter. 29: 39-48.

Reinolds, S.S. (1963). The use of lead citrate of high $\mathrm{pH}$ as an electron-opaque stain in electron microscopy. J. Cell Biol. 17: 208-212.

Sanginga, N. and Van Hove, C. (1989). Amino acid composition of Azolla as affected by strains and population density. Plant and Soil. 117: 263-267.

Selvakumar, V. (2008). Ultraviolet-B radiation $(280-315 \mathrm{~nm})$ invoked antioxidant defense systems in Vigna unguiculata (L.) Walp. And Crotalaria juncea L. Photosynthetica. 46: 98-106.

Singh, N.; Ma, L.Q.; Srivastava, M. and Rathinasabapathi, B. (2006). Metabolic adaptations to arsenic induced oxidative stress in Pteris vittata and Pteris ensiformis L. Plant Sci. 170: 274-282.

Smirnoff, N. (1996). The function and metabolism of ascorbic acid in plants. Ann. Bot. 78: 661-667. 
Solomon, K.R. (2008). Effects of ozone depletion and UV-B radiation on humans and the environment. Atmos. Ocean. 46: 185-202.

Stoyanova, D. and Velikova, V. (1997). Effects of simulated acid rain on chloroplast ultrastructure of primary leaves of Phaseolus vulgaris. Biol. Plant. 40:589-595.

Tarhanen, S. (1998). Ultrastructural responses of the lichen Bryoria fuscesens to simulated acid rain and heavy metal deposition. Ann. Bot. 82:735-746.

Tee, E.S.; Kuladevan, R.; Young, S.I.; Khor, S.C. and Zakiyah, H.O. (1996). Nutrient analysis of foods. Kuala lumpur: Institute Medical for Research.

Ubaldi, A.; Delbono, G.; Fusari, A. and Serventi, P. (2005). Quick HPLC method to determine vitamin E concentration in cow's milk. Ann. Fac. Medic. Vet.di Parma. 25: 101-110.

Van Hove, C.; de Waha Baillonville, T.; Diara, H.F.; Godard, P.; Mai Kodomi, Y. and Sanginga, N. (1987). Azolla collection and selection. Azolla Utilization. In: Proceedings of the Workshop on Azolla Use, Fuzhou, Fujian, China, 31 March 5 April, 1985. Int. Rice Res. Inst., Los Banos, Philippines, pp. 77-87.

Wang, Y.; Feng, H. Qu, Y.; Cheng, J.; Zhao, Z.; Zhang, M.; Wang, X. and An, L. (2006). The relationship between reactive oxygen species and nitric oxide in ultraviolet-B-induced ethylene production in leaves of maize seedlings. Environ. Exp. Bot. 57: 51-56.

Wildi, B. and Lütz, C. (1996). Antioxidant composition of selected high alpine plant species from different altitudes. Plant Cell Environ. 19:138-146.

Young, A.J.; Phillip, D. and Savill, J. (1997). Carotenoids in higher plant photosynthesis. In: Pessaraki M. (ed.), Handbook of photosynthesis, pp. 575- 96. Marcel Dekker, New York. 

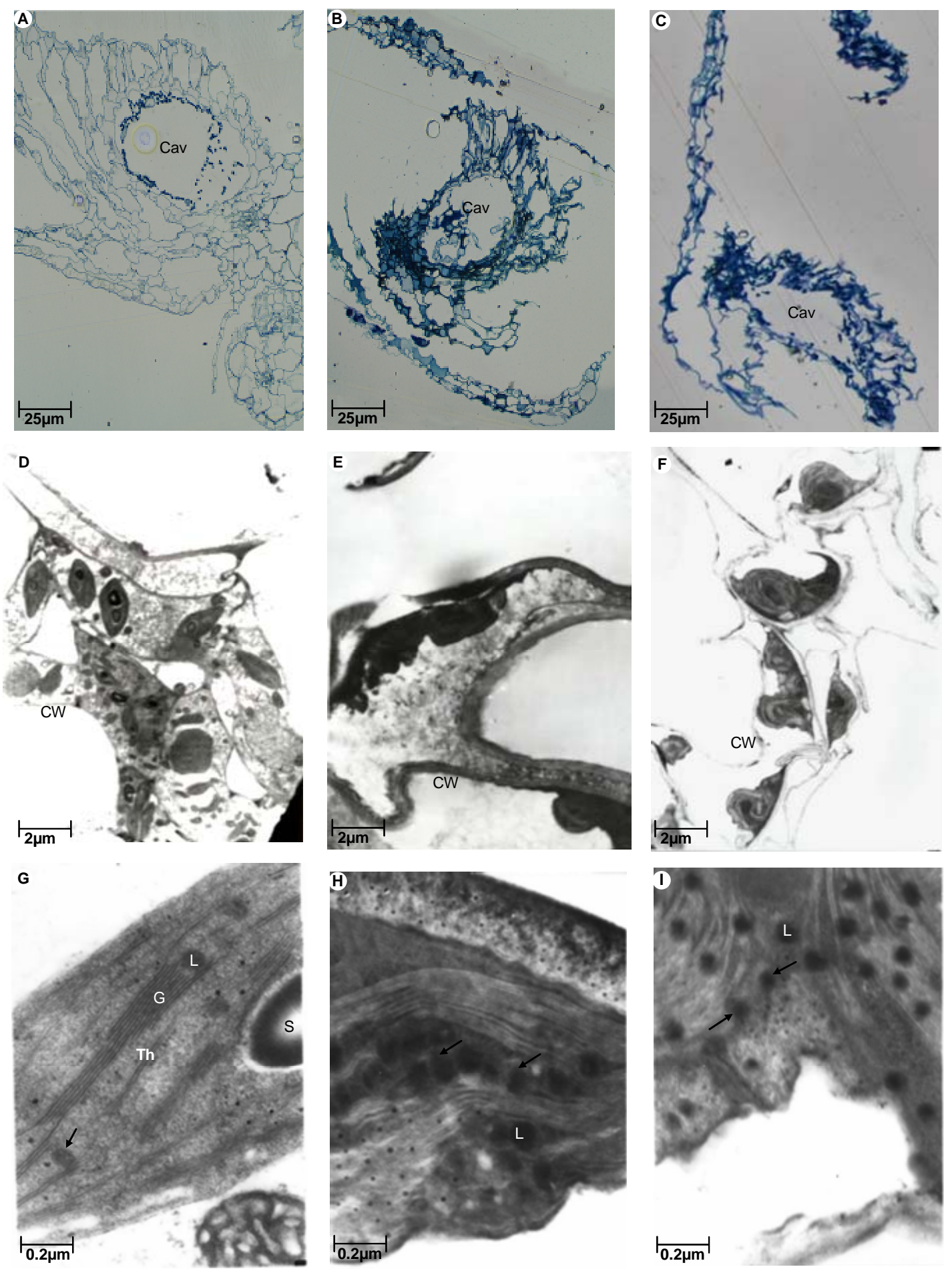

Fig.1: Microscopic photographs (A-C) and electron micrographs (D-I) from A. caroliniana (A) control plants. (B) Cells after $24 \mathrm{~h}$ UV-B treatment. (C) Cells after $48 \mathrm{~h}$ UV-B treatment. (D, G) Control plants, detail of chloroplasts showing large starch granules and few plastoglobuli. (E, H) Cells after $24 \mathrm{~h}$ UV-B treatment, detail of chloroplasts showing few starch granules and large amount of plastoglobuli. (F, I) Cells after 48 h UV-B treatment detail of chloroplasts showing swollen chloroplasts with low density of stroma and strongly wave like thylakoid and most abundant of plastoglobuli. Arrows point to plastoglobuli; Cav, cavity including Anabaena; CW, Cell wall; G, granum stack; L, lipid bodies; S, starch granule; Th, thylakoid. 


\section{ARABIC SUMMARY}

التحليل الكروماتوجرافي للمركبات المضادة للأكسدة في نبات الأزولا المعرض للأشعة فوق البنفسجية

$$
\begin{aligned}
& \text { إعزاز محمد مصطفى و محمد محمد إبراهيم }
\end{aligned}
$$

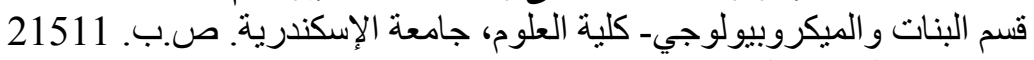

$$
\begin{aligned}
& \text { البريد الإلكتروني: m_ibramim2004@yahoo.com }
\end{aligned}
$$

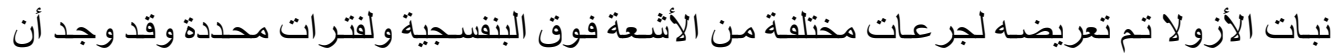

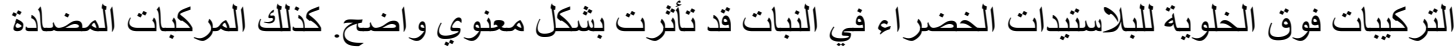

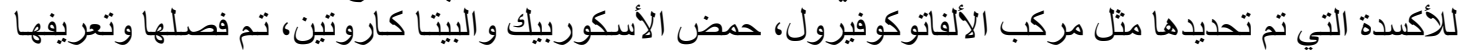

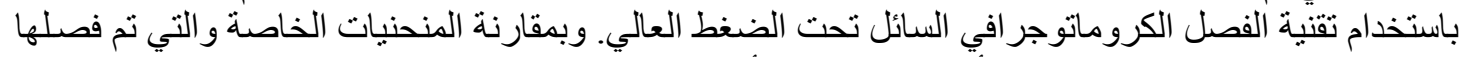

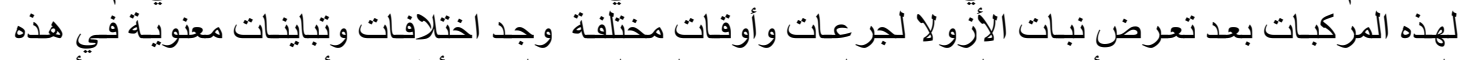

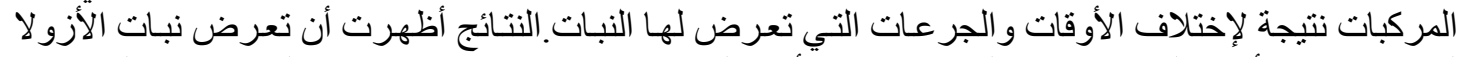

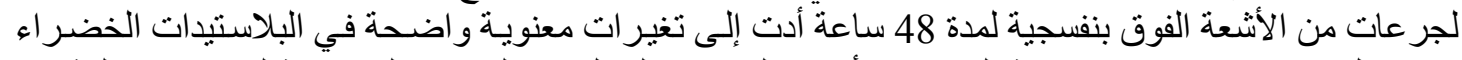

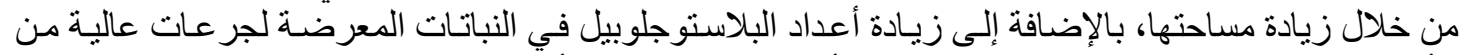

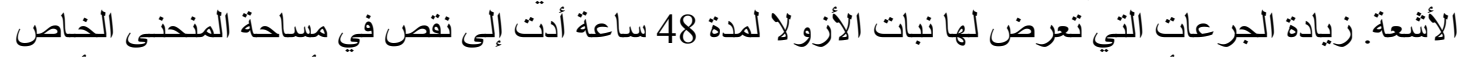

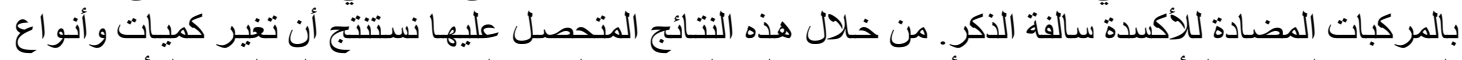

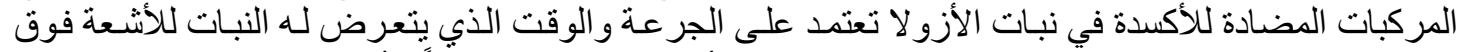
البنفسية. و هذه المركبات لها دور كبير في حماية نبات الأزو لا لحد معين مقاو ماً للأشعة فوق البنفسجية. 